\title{
E-MODUL IPA UNTUK MEMFASILITASI SISWA MENENGAH ATAS BELAJAR MANDIRI
}

\author{
W.S. Sembiring ${ }^{1}$, I.G.W. Sudatha ${ }^{2}$, A.H. Simamora ${ }^{3}$ \\ ${ }^{123}$ Program Studi Teknologi Pendidikan \\ Universitas Pendidikan Ganesha \\ Singaraja, Indonesia

\begin{abstract}
e-mail: widyasartikasembiring@gmail.com ${ }^{1}$, igdewawans@undiksha.ac.id ${ }^{2}$,
\end{abstract} \\ alexander.simamora@undiksha.ac.id ${ }^{3}$
}

\begin{abstract}
Abstrak
Masih banyak guru yang kurang mampu menciptakan sumber belajar interaktif. Hal ini menyebabkan siswa belum sepenuhnya mengerti dan menguasai materi sehingga berdampak pada hasil belajar siswa yang rendah. Tujuan penelitian ini yaitu mencipatakan E-modul IPA untuk siswa sekolah menengah atas kelas 8 . Jenis penelitian ini yaitu penelitian pengembangan. Model yang digunakan dalam mengembangkan media yaitu ADDIE (analisis, desain, pengembangan, implementasi, dan evaluasi). Subjek uji produk terdiri atas 1 ahli isi materi pembelajaran, 1 ahli desain pembelajaran, dan 1 ahli media pembelajaran. Subjek uji coba produk sebanyak 12 siswa. Instrumen yang digunakan dalam mengumpulkan data yaitu kuisioner, dan tes. Teknik analisis data yang digunakan yaitu analisis deskriptif kualitatif dan analisis statistik deskriptif kuantitatif. Hasil penelitian yaitu penilaian yang diberikan oleh ahli isi pelajaran mendapatkan persentase $100 \%$ sehingga mendapatkan kualifikasi sangat baik. Penilaian oleh ahli desain pembelajaran yaitu $92,8 \%$ (sangat baik). Penilaian oleh ahli media pembelajaran yaitu $95,8 \%$ (sangat baik). Penilaian dari uji coba perorangan yaitu $91 \%$ (sangat baik), dan uji coba kelompok kecil yaitu 93,5\% (sangat baik). Dapat disimpulkan bahwa E-modul yang telah dikembangkan valid dan layak diterapkan dalam proses pembelajaran. Implikasi penelitian ini yaitu E-modul yang telah dikembangkan dapat digunakan oleh guru dalam proses pembelajaran, sehingga dapat membantu siswa dalam belajar mandiri.
\end{abstract}

Kata kunci: Belajar Mandiri; E-Modul; IPA

\begin{abstract}
There are still many teachers who are not able to create interactive learning resources. This causes students to not fully understand and master the material so that it has an impact on low student learning outcomes. The purpose of this study is to create an E-module in science lessons for 8th grade high school students. This type of research is development research. The model used in developing the media is ADDIE (analysis, design, development, implementation, and evaluation). The product test subjects consisted of 1 learning material expert, 1 learning design expert, and 1 learning media expert. The product trial subjects were 12 students. The methods used to collect data are questionnaires and tests. The instruments used in collecting data are questionnaires, and test questions. The data analysis technique used is descriptive qualitative analysis and descriptive quantitative statistical analysis. The results of the study are the assessments given by subject matter experts get a percentage of 100\% so that they get very good qualifications. Assessment by learning design experts is $92.8 \%$ (very good). The assessment by learning media experts is $95.8 \%$ (very good). The assessment of the individual trial is $91 \%$ (very good), and the small group trial is $93.5 \%$ (very good). It can be concluded that the E-module that has been developed is valid and feasible to be applied in the learning process. The implication of this research is that the developed E-module can be used by teachers in the learning process, so that it can help students in independent learning.
\end{abstract}

Keywords : Independent Learning; E-Modul; Science 


\section{PENDAHULUAN}

Perkembangan Iptek yang sangat pesat berdampak perubahan yang sangat besar pada seluruh sektor, salah satunya yaitu Pendidikan (Hamilton et al., 2021; Hussin, 2018; Tuma, 2021). Saat ini teknologi sangat dibutuhkan dalam dunia Pendidikan sehingga guru wajib untuk dapat memanfaatkan teknologi dengan baik sehingga dapat membantu pelaksanaan pembelajaran (Chang et al., 2021; Yavuz et al., 2021). Teknologi dapat digunakan sebagai sarana yang dapat mendukung proses pembelajaran, sebagai alat informasi dan juga sebagai alat pembelajaran. Saat ini keadaan pandemic covid-19 juga menuntut sekolah dan guru untuk melaksanaan pembelajaran secara online (Shah et al., 2020; Yulia, 2020). Hal ini bertujuan untuk mencegah penularan Covid-19 yang sangat berbahaya bagi manusia. Guru dituntut untuk dapat melaksanakan pembelajaran secara online agar siswa dapat belajar walaupun secara online (Lim et al., 2021; Rafique et al., 2021). Berbagai platform dapat digunakan dalam pembelajaran daring seperti ZOOM, Google Meet, dan Schoology. Hal ini tentu menjadi tantangan bagi guru. Selain itu, guru dituntut untuk dapat memfasilitasi siswa dengan memberikan sumber belajar yang efisien, sehingga siswa dapat belajar secara mandiri (Handayani et al., 2021; Istuningsih et al., 2018). Sumber belajar yang saat ini dibutuhkan oleh siswa yaitu sumber belajar yang mudah diakses oleh siswa sehingga siswa menjadi dimudahkan dalam belajar (Imansari \& Sunaryantiningsih, 2017; Irwandani et al., 2017). Guru diwajibkan untuk dapat memilih serta menggunakan sumber belajar yang tepat sehingga proses pembelajaran daring dapat berjalan secara maksimal (Komikesari et al., 2020; Tchen et al., 2018). Guru dapat menfaatkan teknologi untuk mengembangan media pembelajaran, sumber belajar, ataupun bahan ajar yang menarik dan interaktif. Sumber belajar ini akan membantu siswa dalam memahami materi pembelajaran sehingga akan berdampak pada kemampuan siswa yang meningkat (Majid et al., 2012; Rasmawan, 2018).

Permasalahan yang terjadi saat ini yaitu masih banyak guru yang kurang mampu menciptakan sumber belajar interaktif (Herawati \& Muhtadi, 2018; Nurlaili, 2018; Sidiq \& Najuah, 2020). Permasalahan ini juga ditemukan di sekolah menengah pertama. Berdasarkan hasil observasi di SMP Lab Undiksha ditemukan permasalahan yaitu proses pembelajaran belum berjalan dengan optimal. Hasil wawancara yang dilakukan dengan salah satu guru pengampu mata pelajaran IPA juga ditemukan bahwa siswa belum sepenuhnya mengerti dan menguasai materi. Hal ini disebabkan karena berbagai faktor seperti, guru kurang memanfaatkan bahan ajar digital dimasa pandemi covid-19, penggunaan bahan ajar yang kurang memberikan keleluasaan bagi siswa untuk belajar mandiri, guru masih menggunakan bahan ajar yang bersifat konvensional sehingga nilai yang diperoleh siswa belum memenuhi kriteria nilai minimun. Namun pada situasi pandemi saat ini siswa diharapkan untuk dapat belajar secara mandiri karena pada situasi saat ini tidak memungkinkan jika guru harus selalu mendampingi siswa seperti yang dilakukan pada saat belajar tatap muka (Ambarita, 2021; Laksana, 2020). Hal ini terlihat dari nilai yang diperoleh oleh siswa baik itu nilai tugas, nilai sehari-hari dan nilai ujian yang tergolong masih rendah. Berdasarkan hasil analisis data juga didapatkan bahwa nilai rata-rata hasil UTS siswa kelas VIII pada mata pelajaran IPA tahun ajaran 2020/2021 yaitu 70. Terdapat 6 dari 29 siswa yang mampu melewati nilai KKM yang di tetapkan sekolah. Oleh karena itu dpat disimpulakan bahwa siswa membutuhkan bahan ajar bersifat mengajak dan memfasilitasi siswa untuk belajar IPA secara mandiri.

Pembelajaran IPA merupakan wahaa bagi siswa untuk mempelajaria diri sendiri dan alam sekitar. IPA adalah ilmu pengetahhuan yang mempelajaran alam 
disekitar secara ilmiah (Ardaya, 2016; Krishna et al., 2015). Proses pembelajaran IPA menekankan pada pengalaman langsung untuk mengembangkan kompetensi siswa sehingga siswa dapat menjelajahi dan memahami alam sekitar secara ilmiah (Hadiyati \& Wijayanti, 2017; Wiyono et al., 2018). Dalam pelakasanaan pembelajaran IPA guru dituntut untuk dapat mencapai tujuan pembelajaran. Selain itu, guru juga dituntut mampu meningkatkan motivasi belajar dan suasana belajar menyenangkan sehingga akan memudahkan siswa dalam belajar (Khan et al., 2019; Sun \& Gao, 2016). Dalam menciptakan suasana belajar yang nyaman dan menyenangkan guru harus mampu menghadirkan situasi nyata dan mampu mendorong siswa untk membuat hubungan antara pengetahuan yang dimilikinya dengan penerapannya dalam kehidupan sehari-hari (Dupri et al., 2020; Sung, 2017). Hal ini juga dapat melatih siswa untuk belajar secara mandiri.

Berdasarkan permasalahan tersebut, maka salah satu solusi yang ditawarkan agar sisa dapat belajar secara mandiri yaitu pengembangan bahan ajar digital. Bahan ajar digital dapat membuat siswa belajar dengan mudah karena dapat diakses kapansaja (Handayani et al., 2021; Tambunan et al., 2020; Winatha et al., 2018). Salah satu bahan ajar yang dapat digunakan oleh guru yaitu E-modul. E-modul dapat menjadi solusi bagi siswa yang belajar secara mandiri karena E-modul bersifat interaktif sehingga memudahkan siswa dalam belajar (Istuningsih et al., 2018; Komikesari et al., 2020). E-modul adalah modul elektronik yang merupakan sebuah bahan ajar yang penyajiannya secara sistematis sehingga memudahkan siswa dalam belajar mandiri (Alias \& Siraj, 2012; Asrial et al., 2020). Setiap materi pembelajaran akan dihubungkan dengan link sebagai navigasi sehingga membuat siswa merasa nyaman dalam belajar. Emodul juga dapat di akses dengan mudah melalui smartphone, sehingga akan menarik minat siswa untuk belajar (Majid et al., 2012; Seruni et al., 2020). Siswa memiliki sumber belajar yang menarik dan juga interaktif yang dapat menjawab rasa keingintahuan mereka, maka hal ini akan dapat menungkatkan dan melancarkan proses belajar siswa (Alias \& Siraj, 2012; Rasmawan, 2018). E-modul juga dapat menyajikan video pembelajaran yang dapat membuat siswa lebih mudah menyerap informasi yang disajikan.

Penelitian sebelumnya menyatakan bahwa E-modul akan memudahkan siswa dalam belajar (Irwansyah et al., 2017; Safitri, 2017; Sunismi \& Fathani, 2016). Temuan penelitian lainnya juga menyatakan bahwa E-modul membuat siswa merasa nyaman dalam belajar sehingga dapat meningkatkan hasil belajar siswa (Canboy et al., 2016; Lee \& Osman, 2012). Belum adanya kajian mengenai pengembangan Emodul pada pelajaran IPA untuk siswa sekolah menengah atas kelas 8 . Kelebihan E-modul yang akan dikembangkan yaitu Emodul yang akan dikembangkan dilengkapi dengan penyajian video tutorial, animasi dan audio untuk memperkaya pengalaman belajar. Selain itu dengan adanya E-modul ini siswa akan dimudahkan dalam belajar seara mandiri. Tujuan penelitian ini yaitu untuk menciptakan E-modul pada pelajaran IPA untuk siswa sekolah menengah atas kelas 8. Diharapkan media ini dapat digunakan oleh siswa dalam belajar secara mandiri sehingga berdampak pada pemahaman siswa yang meningkat.

\section{METODE}

Jenis penelitian ini yaitu penelitian pengembangan. Model yang digunakan dalam mengembangkan media E-modul pada pelajaran IPA untuk siswa sekolah menengah atas kelas 8 yaitu ADDIE yang memiliki lima tahapan yaitu analisis, desain, pengembangan, implementasi, dan evaluasi (Tegeh dan Jampel, 2017). Pada tahap analisis dilakukan menganalisis permasalahan yang terjadi dilapangan dan analysis siswa. Pada tahap desain yaitu 
merumuskan tujuan pembelajaran, mendesain E-modul yang akan dikembangkan. Pada tahap implementasi yaitu uji validasi produk yang dikembangkan berupa E-modul. Pada tahap evaluasi yaitu mengevaluasi E-modul yang telah dikembangkan dengan cara merevisi produk berdasarkan hasil masukan dari para ahli.

Subjek uji produk terdiri atas 1 ahli materi pembelajaran, 1 ahli desain pembelajaran, dan 1 ahli media pembelajaran. Subjek uji coba produk terdiri dari 3 orang siswa (uji coba perorangan), dan 9 orang siswa (uji coba kelompok kecil). Jenis data penelitian yaitu data kualitatif dan kuantitatif. Data kualitatif diperoleh dari tanggapan kuesioner ahli dan uji coba produk. Data kuantitatif diperoleh dari penilaian yang diberikan oleh ahli dan uji coba produk. Metode yang digunakan untuk mengumpulkan data yaitu kuesioner dan tes. Metode kuesioner digunakan saat uji validasi produk. Metode tes digunakan saat mengukur kemampuan siswa. Instrumen yang digunakan dalam mengumpulkan data yaitu kuisioner dan tes. Adapun Aspek yang terdapat pada kuesioner ahli isi pelajaran yaitu materi dan evaluasi. Aspek yang terdapat pada instrumen ahli desain pembelajaran yaitu tujuan, strategi, dan evaluasi. Aspek yang terdapat pada instrumen ahli media pembelajaran yaitu desain pesan dan pengoperasian. Aspek yang terdapat pada instrumen uji coba produk yaitu desain pesan, evaluasi, dan materi. Teknik analisis data yang digunakan dalam penelitian ini yaitu teknik analisis deskriptif kualitatif, analisis statistik deskriptif kuantitatif. Teknik analisis deskriptif kualitatif digunakan untuk mengolah data yang diperoleh melalui angket berupa tanggapan ahli dan siswa. Hasil analisis ini kemudian digunakan untuk merevisi produk yang dikembangkan. Teknik analisis deskriptif kuantitatif digunakan dalam mengolah data berapa angka/ nilai yang diberikan oleh ahli dan siswa. Untuk mengambil keputusan digunakan ketetapan konvensi tingkat pencapaian skala 4 (Arikunto, 2008). Adapun konvensi Tingkat pencapaian dengan skala 4 disajikan pada tabel 1 .

Tabel 1. Konvensi Tingkat Pencapaian dengan Skala 4

\begin{tabular}{ccc}
\hline $\begin{array}{c}\text { Interval Tingkat } \\
\text { Pencapaian }\end{array}$ & Kualifikasi & Keterangan \\
\hline $80-100$ & Sangat baik & Tidak perlu direvisi \\
$60-79$ & Baik & Sedikit direvisi \\
$40-59$ & Cukup & Direvisi secukupnya \\
$0-39$ & Kurang & Banyak hal yang direvisi \\
\hline
\end{tabular}

\section{HASIL DAN PEMBAHASAN}

Tahap pertama yang dilakukan yaitu Analisis. Kegiatan yang dilakukan pada tahap ini yaitu mengidentifikasi mata pelajaran, mengamat, menganalisis kegitan belajar dan mengamati fasislitas belajar siswa. Berdasarkan hasil analisis kegiatan belajar ditemukan bahwa siswa belum mampu belajar secara mandiri. Selain itu kurangnya media pembelajaran membuat siswa merasa cepat bosan dalam belajar. Hasil analisis fasilitas belajar didapatkan bahwa terdapat fasilitas belajar yang dapat mendukung pembelajaran online serta siswa memiliki keterampilan dalam mengoprasikan komputer maupun laptop dengan baik dapat mendukung siswa dalam mengakses bahan ajar elektronik (E-modul) pada mata pekajaran IPA kela VII di SMP Lab Undiksha.

Tahap kedua yang dilakukan yaitu desain. Pada tahap ini yang dilakukan yaitu membuat flowchart dan storyboard E-modul. Adapun tujuan dibuatnya flowchart dan storyboard adalah untuk mengetahui 
bagaimana alur kerja atau rancangan awal dalam mengembangkan susatu E-modul. Penyusunan krangkan E modul dilakukan dengan membuat garis besar E-modul dan sistematika materi yang akan dikembangkan. Kerangka yang sudah dirancang tersebut akan mempermudah penyusunan E-modul yang dikembangkan. Dalam mendesain tampilan E-modul digunkan jenis huruf Arial Black dengan ukuran 36 point tulisan E- Modul, 28 point untuk IPA, 24 point untuk kelas dan 16 point untuk semester dan jarak antar line yaitu 1,5 sehingga memberikan kenyaman bagi siswa untuk menyimak materi yang disajika dalam E-modul. Adapun desain sampul dan Isi ada E-modul disajikan pada gambar 2. Pada tahap ini juga Menyusun isntrumen penilaian dan Menyusun RPP (Rencana Pembelajaran).
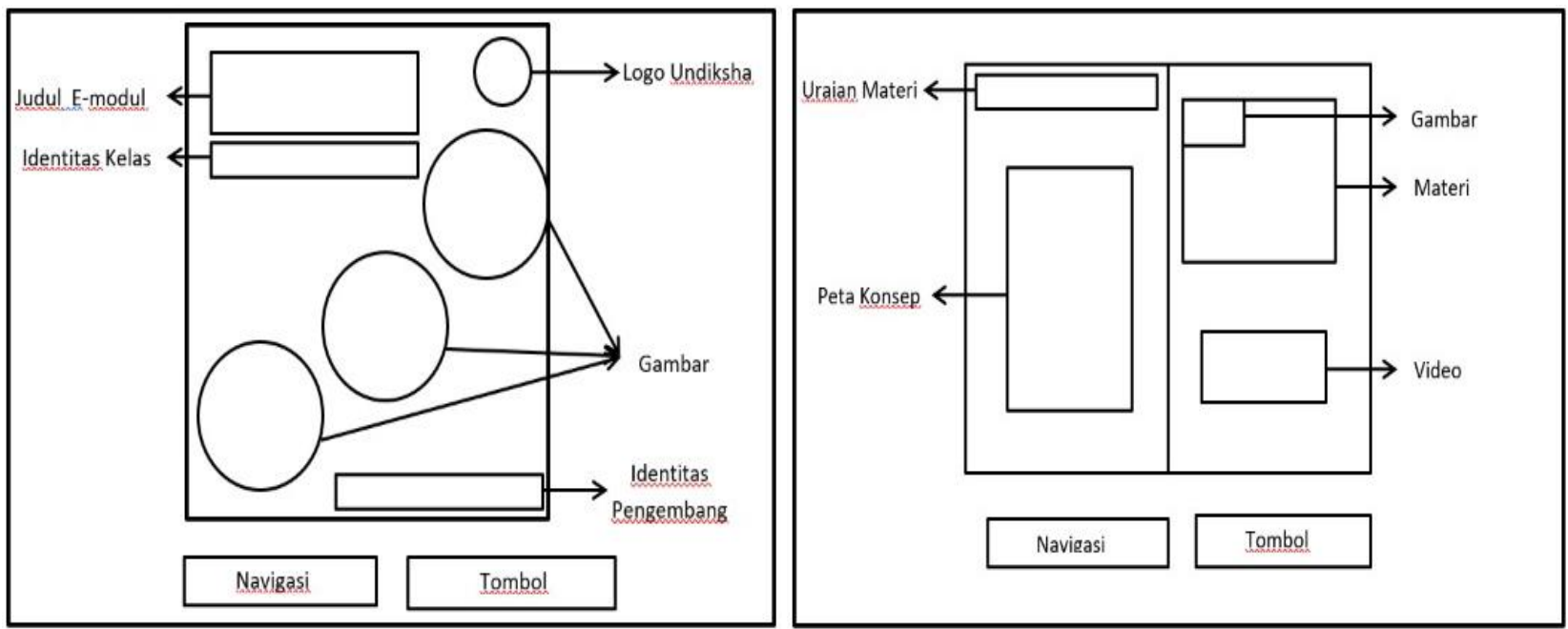

Gambar 2. Desain Sampul dan Isi E-Modul

Tahap ketiga yaitu pengembangan. Pada tahap ini kegiatan yang dilakukan yaitu mengembangkan E-modul IPA. Kegiatan awal yang dilakukan yaitu mengumpulkan materi bahan ajar yang di peroleh melalui buku ajar IPA kelas VIII dan sumber lain yang relevan dengan materi yang diangkat. Aplikasi utama yang digunakan dalam mengembangkan E-modul seperti teks, gambar, video dan kuis dengan menggunakan aplikasi Flip PDF Profesional, sehingga menjadi bahan ajar electronik. Setelah materi dikembangkan menjadi E- modul dan mejadi bahan ajar, dilanjutkan dengan pembuatan E-modul mejadi bahan ajar yang dapat diakses melalui laptop, komputer, maupun android. Penyusunan materi E-modul sudah menerapkan prinsip desain pesan, yaitu dalam penyusuna materi telah mengunakan huruf Arial dengan ukuran 12 point dan jaraj antar line yatu 1,5. Penyusunan komponen isi E-modul dilakukan dengan mengatur keseimabangan antara komponen teks dan gambar. Adapun hasil pengembangan E-modul disajikan pada gambar 3 . 


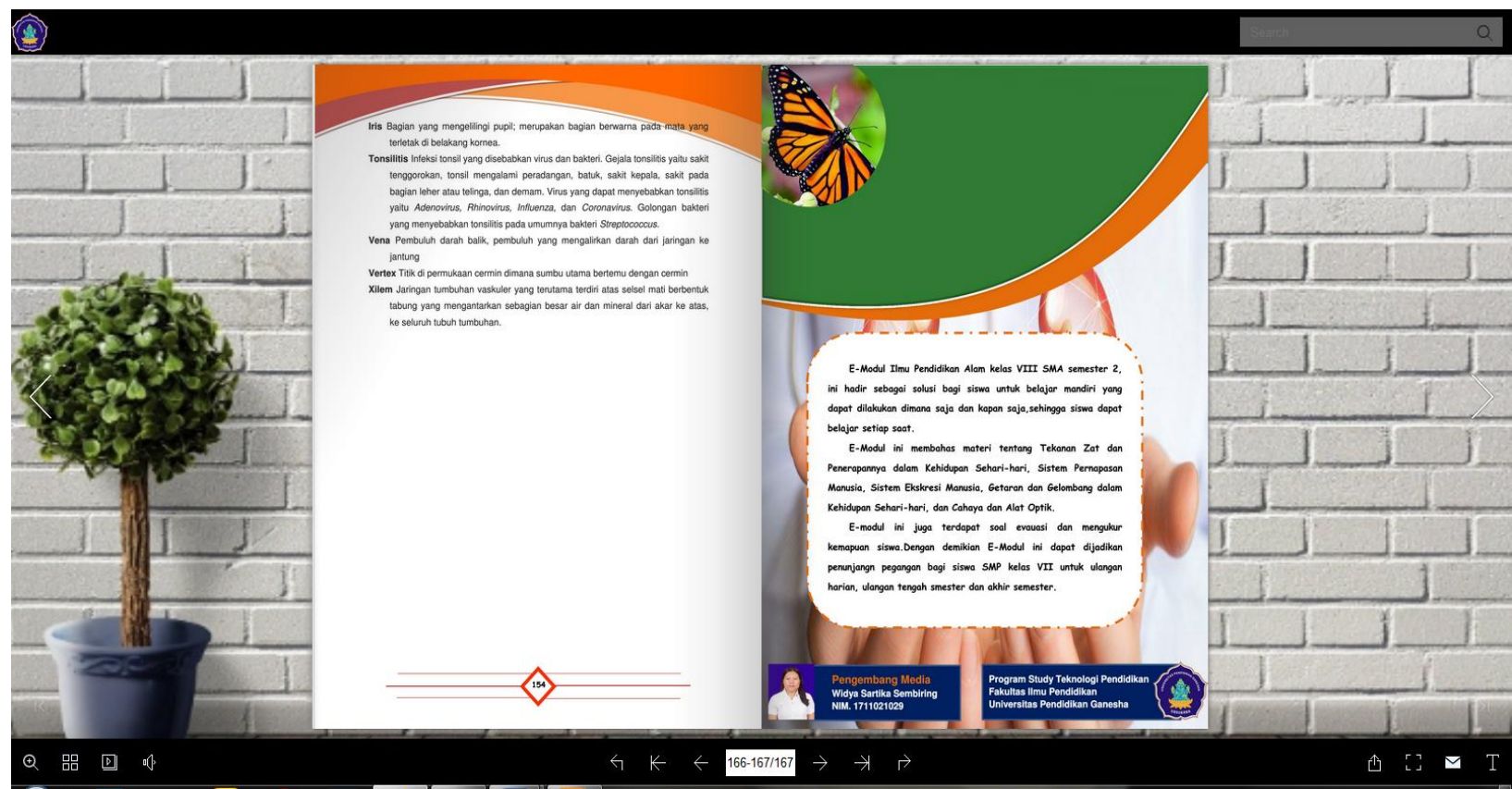

Gambar 3. E-modul IPA yang telah dikembangkan

Tahap empat yaitu implementasi. Pada tahap ini kegiatan yang dilakukan yaitu menilai produk yang telah dikembangkan berupa E-modul pada mata pelajaran IPA yang dilakukan oleh para ahli. Selanjutnya media yang telah dinyatakan valid akan diuji coba oleh siswa. Berdasarkan penilaian yang diberikan oleh ahli isi pelajaran terhadap produk yang dikembangkan E-modul pada mata pelajaran IPA mendapatkan persentase $100 \%$. Pada tabel koversi tingkat pencapaian skala 4 , nilai tersebut berada pada rentang 90-100\% sehingga mendapatkan kualifikasi sangat baik sehingga pada aspek ini mata pelajaran Emodul tidak perlu direvisi. Hasil penilaian yang diberikan oleh ahli desain pembelajaran, E-modul yang dikembangkan mendapatkan persentase $92,8 \%$ sehingga mendapatkan kualifikasi sangat baik sehingga pada aspek ini mata pelajaran E- modul tidak perlu direvisi. Hasil penilaian yang diberikan oleh ahli media pembelajaran mendapatkan dengan persentase $95,8 \%$, sehingga mendapatkan kualifikasi sangat baik sehingga pada aspek ini mata pelajaran E-modul tidak perlu direvisi. Berdasarkan hasil penilaian tersebut maka dapat disimpulkan bahwa Emodul yang dikembangkan mendapatkan kualifikasi sangat baik. Adapun beberapa masukan yang diberikan oleh ahli yaitu 1) pada cover setiap kegiatan belajar terdapat teks yang berhimpitan dengan gambar, perlu diatur lagi, 2) rapikan tata letak teks dan gambar, Pada Soal evaluasi perlu di tambahkan soal AKM yang mengasah wawasan siswa. Masukan tersebut digunakan untuk menyempurnakan produk yang telah dikembangkan. Selanjutnya Emodul yang ditelah dikembangkan direvisi sesuai masukan dari ahli. Adapun hasil revisan E-modul disajikan pada gambar 4. 

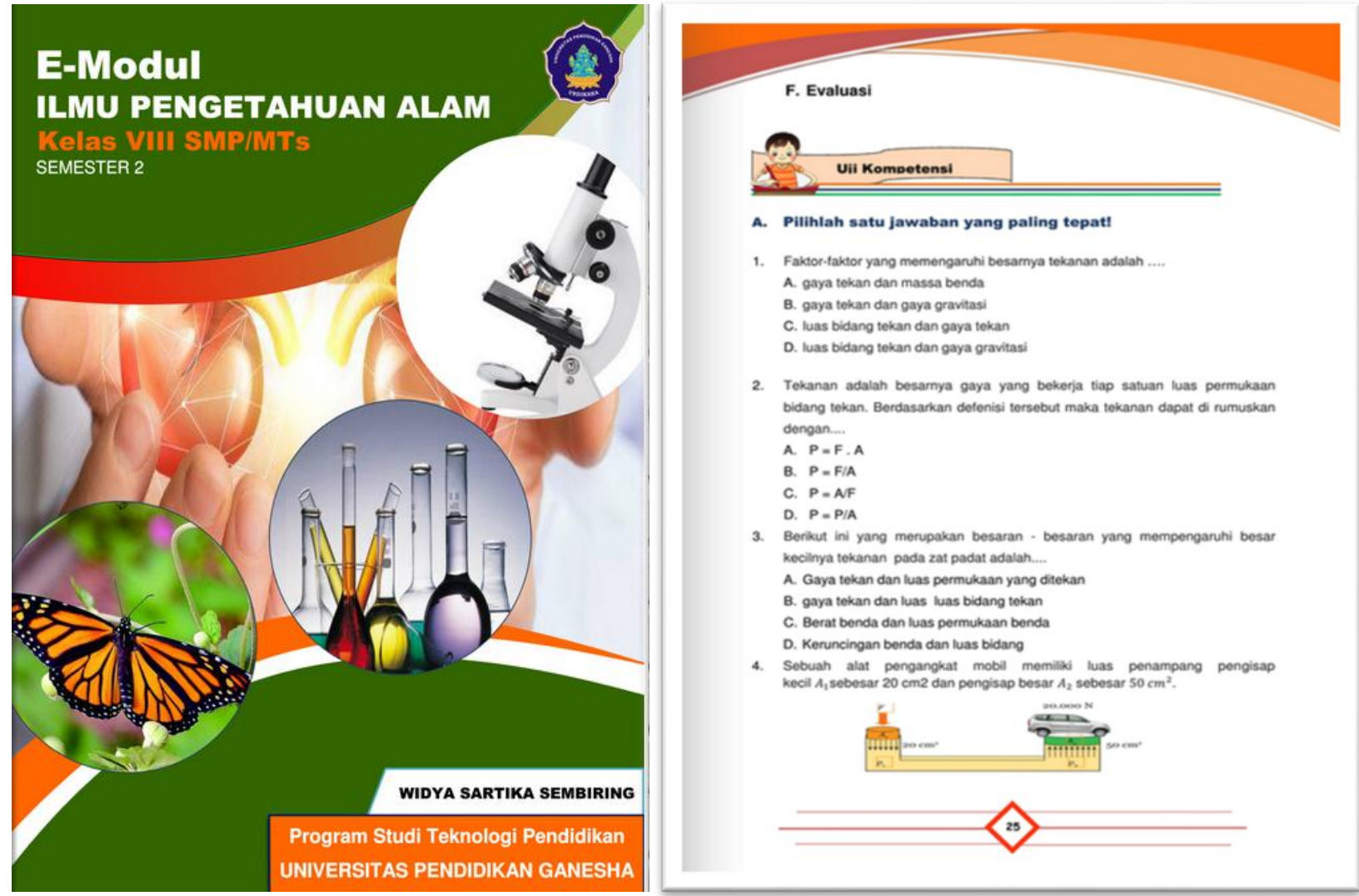

Gambar 4. Hasil Revisian E-modul

Setelah E-modul direvisi sesuai masukan dari para ahli, kemudian Langkah selanjutnya yaitu menguji validitas E-modul oleh siswa melalui uji coba perorangan dan kelompok kecil. Hasil penilaian yang didapatkan dari uji coba perorangan didapatkan hasil yaitu $911 \%$ sehingga berada pada kualifikasi sangat baik dan Emodul tidak perlu direvisi. Hasil penilaian yang didapatkan dari uji coba kelompok kecil yaitu 93,5\% sehingga berada pada kualifikasi sangat baik dan E-modul tidak perlu direvisi. Sehingga dapat disimpulkan bahwa E-modul yang telah dikembangkan valid dan layak diterapkan dalam proses pembelajaran. Hal ini disebabkan oleh beberapa factor yaitu sebagai berikut.

Pertama, E-modul yang telah dikembangkan layak diterapkan dalam proses pembelajaran karena mendapatkan kualifikasi sangat baik. Kualifikasi sangat baik dapat dicapai karena beberapa hal yaitu pertama kejelasan identitas, indikator pembelajaran, dan tujuan pembelajaran pada E-modul. Kejelasan identitas, indicator, serta tujuan pembelajaran akan memudahkan siswa mengetahui tujuan pembelajaran yang hendak dicapai oleh siswa (Aufa et al., 2021; Wijayanti et al., 2016). Kedua, kesesuaian sistematika, isi materi yang disajikan dala E-modul. Sistematika modul yang tepat akan memudahkan siswa dalam belajar sehingga siswa tidak merasa bingung Ketika mencari materi pembelajaran yang hendak ingin dibaca (Sadimin et al., 2017; Sofyan et al., 2019). Ketiga yaitu kejelasan Bahasa. Bahasa yang digunakan pada E-modul sangat jelas sehingga informasi yang disajikan akan tersampaikan dengan baik (Astra et al., 2020; Fonda \& Sumargiyani, 2018). Penyajian materi secara runtut akan lebih menarik dan mudah dipahami oleh 
siswa (Astra et al., 2020; Elder et al., 2019). Kejelasan indikator dan tujuan pembelajaran akan meningkatkan kulitas pembelajaran yang lebih baik (Resita \& Ertikanto, 2018).

Kedua, E-modul yang telah dikembangkan layak diterapkan dalam proses pembelajaran karena memudahkan siswa dalam memahami materi. Perencanaan pembelajaran yang baik akan mempermudah proses proses pembelajaran dan dapat berjalan dengan maksimal, serta dengan adannya evaluasi pembelajaran akan bermanfaat dalam mengetahui sejauh apa pengetahuan siswa dalam belajar (Ningsih \& Mahyuddin, 2021; Setiyani et al., 2020). Konten pada E-modul akan memudahkan siswa dalam memahami penjelasan materi dengan interaktivitas secara pencampuran elemen multimedia ke dalam e-modul (Asrial et al., 2020; Hamzah \& Mentari, 2017). Kelengkapan media belajar dapat mempengaruhi hasil belajar siswa menjadi lebih baik (Faidah et al., 2019; Mastroleo et al., 2020). Modul ini sesungguhnya merupakan modul yang di konversikan ke dalam bentuk digital dengan bantuan alat eletronik yang telah dirancang sebelumnya dari segi desain yang menarik dan dapat diakses dimana saja. E-modul yang dikembangkan juga dilengkapi dengan navigasi, gambar, audio, dan video, sehingga hal ini menjadi kelebihan dari Emodul.

Ketiga, E-modul yang telah dikembangkan layak diterapkan dalam proses pembelajaran menciptakan suasana belajar menyenangkan bagi siswa. Pada Emodul ini juga memberikan fasilitas video pembelajaran yang membuat siswa tertarik dalam belajar. Ketersediaan media belajar yang menarik seperti video pembelajaran akan mampu meningkatkan motivasi siswa dalam belajar sehingga akan meningkatkan hasil belajar siswa (Hamzah \& Mentari, 2017; Triwahyuningtyas et al., 2020). Selain itu, kemudahan dalam penggunaan E-modul akan memberi kenyamanan siswa dalam mengakses materi ajar secara mandiri (Rasmussen et al., 2020; Toma \& Greca,
2018). Tampilan media pembelajaran yang menarik dapat memotivasi siswa dalam belajar, serta bahasa komunikatif dapat membuat siswa lebih mudah memahami materi pembelajaran (Boyd, 2019; Elder et al., 2019). Hal ini yang menyebabkan suasana belajar siswa menjadi menyenangkan.

Temuan penelitian sebelumnya menyatakan bahwa E-modul memberikan kemudahan belajar bagi siswa (Canboy et al., 2016; Lee \& Osman, 2012). Temuan penelitian lainnya juga menyatakan bahwa E-modul meningkatkan semangat dan hasil belajar siswa (Alias \& Siraj, 2012; Asrial et al., 2020; Sunismi \& Fathani, 2016). Dapat disimpulkan bahwa E-modul ini memudahkan siswa dalam belajar. . Kelebihan E-modul yang akan dikembangkan yaitu E-modul dilengkapi dengan penyajian video tutorial, animasi dan audio untuk memperkaya pengalaman belajar sehingga cocok digunakan oleh siswa. Implikasi penelitian ini yaitu E-modul yang telah dikembangkan dapat digunakan oleh guru dalam proses pembelajaran, sehingga dapat membantu siswa dalam belajar mandiri.

\section{PENUTUP}

E-modul yang telah dikembangkan mendapatkan kategori sangat baik dari para ahli dan uji coba produk. Sehingga dapat disimpulkan bahwa E-modul materi pembelajaran IPA valid sehingga layak diterapkan dalam proses pembelajaran. Direkomendasikan kepada guru untuk menggunakan E-modul sehingga dapat membantu siswa belajar secara mandiri.

\section{DAFTAR PUSTAKA}

Alias, N., \& Siraj, S. (2012). Effectiveness of Isman Instructional Design Model in Developing Physics Module based on Learning Style and Appropriate Technology. Procedia - Social and Behavioral Sciences, 64. https://doi.org/10.1016/j.sbspro.2012.1 1.002 
Improvements in the UK OpenUniversity. Journal of Interactive Media in Education, 2019(1), 1-7. https://doi.org/10.5334/jime.529

Canboy, B., Montalvo, A., Buganza, M. C., \& Emmerling, R. J. (2016). 'Module 9': a new course to help students develop interdisciplinary projects using the framework of experiential learning theory. Innovations in Education and Teaching International, 53(4), 445457.

https://doi.org/10.1080/14703297.201 4.975150

Chang, H.-Y., Wu, H.-F., Chang, Y.-C., Tseng, Y.-S., \& Wang, Y.-C. (2021). The effects of a virtual simulationbased, mobile technology application on nursing students' learning achievement and cognitive load: Randomized controlled trial. International Journal of Nursing Studies, 120. https://doi.org/10.1016/j.ijnurstu.2021. 103948

Dupri, D., Candra, O., Candra, A., \& Suryani, D. A. (2020). The Implementation of Problem Based Learning Model in Improving Cooperation and Learning Outcomes in Physical Education. Jurnal Pendidikan Jasmani Dan Olahraga, 5(1).

https://doi.org/10.17509/jpjo.v5i1.2253 1

https://doi.org/10.21009/1.06205

Aufa, M. N., Rusmansyah, R., Hasbie, M., Jaidie, A., \& Yunita, A. (2021). The Effect of Using e-module Model Problem Based Learning (PBL) Based on Wetland Environment on Critical Thinking Skills and Environmental Care Attitudes. Jurnal Penelitian Pendidikan IPA, 7(3), 401-407. https://doi.org/10.29303/jppipa.v7i3.73 2

Boyd, L. (2019). Using Technology-Enabled Learning Networks to Drive Module
Elder, J. J., Franco, K. A., Gulley, S. L., Hughes, C. T., \& Infanti, L. M. (2019). Implementation of Required Electronic Learning Modules to Enhance Nursing Pharmacotherapy Knowledge of Select Hematopoietic Stem Cell Transplant Topics. Biology of Blood and Marrow Transplantation, 25(3), S303.

https://doi.org/10.1016/j.bbmt.2018.12. 655

Faidah, N., Masykur, R., Andriani, S., \& Lina 
Herlina. (2019). Realistic Mathematics Education ( Rme ) Sebagai Sebuah Pendekatan Pada Pengembangan Modul Matematika Berbasis Teori Multiple Intelligences Realistic Mathematics Education ( Rme ) As an Approach To Development of Mathematical Module Based on Multiple Intel. Indonesia Journal of Science and Mathematics Education, 02(3), 328-332. https://doi.org/10.24042/ijsme.v2i3.43 96

Fonda, A., \& Sumargiyani, S. (2018). The Developing Math Electronic Module With Scientific Approach Using Kvisoft Flipbook Maker Pro For Xi Grade Of Senior High School Students. Infinity Journal, $\quad 7(2)$, 109-122. https://doi.org/10.22460/infinity.v7i2.p1 09-122

Hadiyati, N., \& Wijayanti, A. (2017). Keefektifan Metode Eksperimen Berbantu Media Benda Konkret Terhadap Hasil Belajar IPA Siswa Kelas V Sekolah Dasar. JIPVA (Jurnal Pendidikan IPA Veteran), 1(1). https://doi.org/10.31331/jipva.v1i1.513

Hamilton, D., McKechnie, J., Edgerton, E., \& Wilson, C. (2021). Immersive virtual reality as a pedagogical tool in education: A systematic literature review of quantitative learning outcomes and experimental design. Journal of Computers in Education, 8(1). https://doi.org/10.1007/s40692020-00169-2.

Hamzah, I., \& Mentari, S. (2017). Development of Accounting E-Module to Support the Scientific Approach of Students Grade X Vocational High School. Journal of Accounting and Business Education, 1(1), 78. https://doi.org/10.26675/jabe.v1i1.975 1

Handayani, D., Elvinawati, E., Isnaeni, I., \& Alperi, M. (2021). Development Of
Guided Discovery Based Electronic Module For Chemical Lessons In Redox Reaction Materials. International Journal of Interactive Mobile Technologies (IJIM), 15(07), 94.

https://doi.org/10.3991/ijim.v15i07.215 59

Herawati, N. S., \& Muhtadi, A. (2018). Pengembangan Modul Elektronik (EModul) Interaktif Pada Mata Pelajaran Kimia kelas XI SMA. Jurnal Inovasi Teknologi Pendidikan, 5(2), 180-191. https://doi.org/10.21831/jitp.v5i2.1542 4

Hussin, A. A. (2018). Education 4.0 Made Simple: Ideas For Teaching. International Journal of Education and Literacy Studies, 6(3). https://doi.org/10.7575/aiac.ijels.v.6n.3 p.92

Imansari, N., \& Sunaryantiningsih, I. (2017). Pengaruh Penggunaan E-Modul Interaktif Terhadap Hasil Belajar Mahasiswa Pada Materi Kesehatan dan Keselamatan Kerja. VOLT: Jurnal IImiah Pendidikan Teknik Elektro, 2(1), 11-16.

https://doi.org/10.30870/volt.v2i1.1478

Irwandani, I., Latifah, S., Asyhari, A., Muzannur, M., \& Widayanti, W. (2017). Modul Digital Interaktif Berbasis Articulate Studio'13: Pengembangan pada Materi Gerak Melingkar Kelas X. Jurnal IImiah Pendidikan Fisika Al-Biruni, 6(2). https://doi.org/10.24042/jipfalbiruni.v6i 2.1862

Irwansyah, F. S., Lubab, I., Farida, I., \& Ramdhani, M. A. (2017). Designing Interactive Electronic Module in Chemistry Lessons. Journal of Physics: Conference Series, 895(1). https://doi.org/10.1088/17426596/895/1/012009

Istuningsih, W., Baedhowi, B., \& Sangka, K. B. (2018). The effectiveness of 
scientific approach using e-module based on learning cycle $7 e$ to improve students' learning outcome. International Journal of Educational Research Review, 3(3). https://doi.org/10.24331/ijere.449313

Khan, T., Johnston, K., \& Ophoff, J. (2019). The Impact of an Augmented Reality Application on Learning Motivation of Students. Advances in HumanComputer Interaction. https://doi.org/10.1155/2019/7208494

Komikesari, H., Mutoharoh, M., Dewi, P. S., Utami, G. N., Anggraini, W., \& Himmah, E. F. (2020). Development of e-module using flip pdf professional on temperature and heat material. Journal of Physics: Conference Series, 1572(1). https://doi.org/10.1088/17426596/1572/1/012017

Krishna, P. D. M., Sudhita, I. W. R., \& Mahadewi, L. P. P. (2015). Pengembangan Media Video Pembelajaran Pada Mata Pelajaran Ipa Siswa Kelas VIII Semester Genap. E-Journal Edutech Universitas Pendidikan Ganesha Jurusan Teknologi Pendidikan, 3(1). https://doi.org/10.2387/jeu.v3i1.5701.

Laksana, D. N. L. (2020). Implementation of Online Learning in The Pandemic Covid-19: Student Perception in Areas with Minimum Internet Access. Journal of Education Technology, 4(4), 509509.

https://doi.org/10.23887/jet.v4i4.29314

Lee, T. T., \& Osman, K. (2012). Interactive Multimedia Module in the Learning of Electrochemistry: Effects on Students' Understanding and Motivation. Procedia - Social and Behavioral Sciences, 46. https://doi.org/10.1016/j.sbspro.2012.0 5.295

Lim, M. T. C., Ramamurthy, M. B., Aishworiya, R., Rajgor, D. D., Tran, A.
P., Hiriyur, P., Kunaseelan, S., Jabri, M., \& Goh, D. Y. T. (2021). School closure during the coronavirus disease 2019 (COVID-19) pandemic - Impact on children's sleep. Sleep Medicine, 78(January 2020), 108-114. https://doi.org/10.1016/j.sleep.2020.12 .025

Majid, M. S. Z. B. A., Ali, M. M. B. A., Rahim, A. A. B. A., \& Khamis, N. Y. B. (2012). The Development of Technical English Multimedia Interactive Module to Enhance Student Centered Learning (SCL). Procedia - Social and Behavioral Sciences, 67, 345-348. https://doi.org/10.1016/j.sbspro.2012.1 1.337

Mastroleo, N. R., Humm, L., Williams, C. M., \& Kiluk, B. D. (2020). Initial testing of a computer-based simulation training module to support clinicians' acquisition of CBT skills for substance use disorder treatment. Journal of Substance Abuse Treatment, 114. https://doi.org/https://doi.org/10.1016/j. jsat.2020.108014

Ningsih, S. Y., \& Mahyuddin, N. (2021). Desain E-Module Tematik Berbasis Kesantunan Berbahasa Anak Usia Dini di Taman Kanak-Kanak. Jurnal Obsesi : Jurnal Pendidikan Anak Usia Dini, 6(1), 137-149. https://doi.org/10.31004/obsesi.v6i1.1 217

Nurlaili, N. (2018). Sumber Belajar Dan Alat Permainan Untuk Pendidikan Anak Usia Dini. Al Fitrah: Journal Of Early Childhood Islamic Education, 2(1). https://doi.org/10.29300/alfitrah.v2i1.1 518

Rafique, G. M., Mahmood, K., Warraich, N. F., \& Rehman, S. U. (2021). Readiness for Online Learning during COVID-19 pandemic: A survey of Pakistani LIS students. The Journal of Academic Librarianship, 47(3), 102346. 
https://doi.org/10.1016/j.acalib.2021.1 02346

Rasmawan. (2018). Development of Chemistry Module for Junior High School Based on Inquiry Accompanied by Performance-Based Assessment. Jurnal Pendidikan Indonesia, $\quad 7(2)$, 111-119. https://doi.org/10.23887/jpiundiksha.v7i2.10617

Rasmussen, E., Goddard, A. G., \& Bayer, D. K. (2020). Use of electronic learning modules can improve medical trainee knowledge regarding anaphylaxis diagnosis and treatment. Annals of Allergy, Asthma \& Immunology, 124(3).

https://doi.org/10.1016/j.anai.2019.12. 018

Resita, I., \& Ertikanto, C. (2018). Designing electronic module based on learning content development system in fostering students' multi representation skills. Journal of Physics: Conference Series, 1022(1), 012025. https://doi.org/10.1088/17426596/1022/1/012025

Sadimin Sadimin, Wahyu Hardyanto, \& Slamet, A. (2017). Developing An EModule-Based Classroom Action Research Management Training Model For Teachers High School. International Journal of Education and Research, 5(2), 79-90. https://doi.org/10.15294/jed.v5i3.1812 3

Safitri, I. (2017). Pengembangan E-Module Dengan Pendekatan Pembelajaran Matematika Realistik Berbantuan Flipbook Maker Pada Materi Bangun Ruang Sisi Datar Kelas Viii Smp. Aksioma, 6(2), 1. https://doi.org/10.26877/aks.v6i2.1397

Seruni, R., Munawaroh, S., Kurniadewi, F., \& Nurjayadi, M. (2020). Implementation of e-module flip PDF professional to improve students' critical thinking skills through problem based learning. Journal of Physics: Conference Series, 1521(4), 1-6. https://doi.org/10.1088/17426596/1521/4/042085

Setiyani, Putri, D. P., Ferdianto, F., \& Fauji, S. H. (2020). Designing a Digital Teaching Module Based on Mathematical Communication in Relation and Function. Journal on Mathematics Education, 11(2), 223236.

https://doi.org/10.22342/jme.11.2.7320 .223-236

Shah, K., Arfan, M., Mahariq, I., Ahmadian, A., Salahshour, S., \& Ferrara, M. (2020). Fractal-Fractional Mathematical Model Addressing the Situation of Corona Virus in Pakistan. Results in Physics, 19, 103560. https://doi.org/10.1016/j.rinp.2020.103 560

Sidiq, R., \& Najuah. (2020). Pengembangan E-Modul Interaktif Berbasis Android Pada Mata Kuliah Strategi Belajar Mengajar. Jurnal Pendidikan Sejarah, 9(1), 1-14. https://doi.org/10.21009/JPS.091.01

Sofyan, H., Anggereini, E., \& Saadiah, J. (2019). Development of E-Modules Based on Local Wisdom in Central Learning Model at Kindergartens in Jambi City. European Journal of Educational Research, 8(4), 11371143. https://doi.org/10.12973/eujer.8.4.1137

Sun, H., \& Gao, Y. (2016). Impact of an active educational video game on children's motivation, science knowledge, and physical activity. Journal of Sport and Health Science 5, 239-245.

https://doi.org/10.1016/j.jshs.2014.12. 004

Sung, E. (2017). The influence of visualization tendency on problemsolving ability and learning 
achievement of primary school students in South Korea. Thinking Skills and Creativity, 26, 168-175. https://doi.org/10.1016/j.tsc.2017.10

Sunismi, S., \& Fathani, A. H. (2016). Uji Validasi E-Module Matakuliah Kalkulus I untuk Mengoptimalkan Student Centered Learning dan Individual Learning Mahasiswa S-1. Jurnal Review Pembelajaran Matematika, 1(2), 174-191. https://doi.org/10.15642/jrpm.2016.1.2 .174-191

Tambunan, L. R., Siregar, N. A. R., \& Susanti, S. (2020). Implementasi Ebook Berbasis Smartphone pada Materi Polinomial di Kelas XI SMA Negeri 4 Tanjungpinang. Jurnal Anugerah.

https://doi.org/10.31629/anugerah.v2i2 .2521

Tchen, P., Leung, L., Simpson, F., KimSing, A., \& Pearson, M. L. (2018). Bridging the gap: An evaluation of self-paced online transition modules for advanced pharmacy practice experience students. Currents in Pharmacy Teaching and Learning, 10(10).

https://doi.org/10.1016/j.cptl.2018.07.0 06

Tegeh dan Jampel. (2017). Metode Penelitian Pengembangan. Universitas Pendidikan Ganesha.

Toma, R. B., \& Greca, I. M. (2018). The effect of integrative STEM instruction on elementary students' attitudes toward science. Eurasia Journal of Mathematics, Science and Technology Education, 14(4), 13831395.

https://doi.org/10.29333/ejmste/83676

Triwahyuningtyas, D., Ningtyas, A. S., \& Rahayu, S. (2020). The problembased learning e-module of planes using Kvisoft Flipbook Maker for elementary school students. Jurnal
Prima Edukasia, 8(2), 199-208. https://doi.org/10.21831/jpe.v8i2.3444 6

Tuma, F. (2021). The use of educational technology for interactive teaching in lectures. Annals of Medicine and Surgery 62, 231-235. https://doi.org/10.1016/j.amsu.2021.01 .051

Wijayanti, N. P. A., Damayanthi, L. P. E., Sunarya, I. M. G., \& Putrama, I. M. (2016). Pengembangan E-Modul Berbasis Project Based Learning Pada Mata Pelajaran Simulasi Digital Untuk Siswa Kelas X Studi Kasus di SMK Negeri 2 Singaraja. Jurnal Pendidikan Teknologi Dan Kejuruan, 13(2), 184-197. https://doi.org/10.23887/jptkundiksha.v13i2.8526

Winatha, K. R., Naswan, S., \& Ketut, A. (2018). Pengembangan E-modul Interaktif Berbasis Proyek Pada Mata Pelajaran Simulasi Digital Kelas $\mathrm{X}$ di SMK TI Bali Global Singaraja. Jurnal Teknologi Pembelajaran Indonesia, 8(1). https://doi.org/10.23887/jtpi.v8i1.2238

Wiyono, B., Hatmokomukti, \& Budhi, W. (2018). Pengaruh Metode Pembelajaran CTL Terhadap Hasil Belajar IPA Siswa Kelas VIII Ditinjau Dari Kemampuan Berkomunikasi. Jurnal IImiah Pendidikan IPA, 5(1), 11-18.

https://doi.org/10.30738/natural.v5i1.2 561

Yavuz, M., Çorbacıoğlu, E., Başoğlu, A. N., Daim, T. U., \& Shaygan, A. (2021). Augmented reality technology adoption: Case of a mobile application in Turkey. Technology in Society, 66. https://doi.org/10.1016/j.techsoc.2021. 101598

Yulia, H. (2020). Online Learning to Prevent the Spread of Pandemic Corona Virus in Indonesia. ETERNAL (English 
DOI : 10.23887/jurnal_tp.v11i1.635 Volume 11 Nomor 1 Tahun 2021

Diterima : 12-09-2021 | Disetujui : 17-09-2021 | Diterbitkan : 28-09-2021

Teaching Journal), 11(1). https://doi.org/10.26877/eternal.v11i1. 6068 